\title{
КАТЕГОРІЯ ІСТОРИЧНОГО ЗАКОНУ І ПРОБЛЕМА СОЦІАЛЬНОГО ДЕТЕРМІНІЗМУ
}

\begin{abstract}
О.П. Панафідіна
Категорію історичного закону зазвичай розглядають в контексті протистояння двох традиційних методологічних підходів до осмислення культурно-історичного руху: детермінізму та індетермінізму. Крайнім вираженням першого 3 них виступає трансформована релігійна ідея про напередвизначеність історичного процесу, що має проходити у своєму розвитку певні обов'язкові стадії, дослідивши які, можна виокремити систему законів суспільного руху і на цій основі передбачити майбутнє. Філософи ж індетерміністичного спрямування виступають проти подібного фаталізму, однак іноді вдаються до іншої крайностіволюнтаризму, абсолютизуючи суб'єктивні чинники розвитку суспільства. Відтак перед дослідниками кожної нової епохи постає проблема найоптимальнішого поєднання принципів закономірного руху історії 3 роллю випадковості та індивідуальної свободи окремих людей.

XX століття позначилося значною ідеологізацією соціальної сфери людського життя. Вона стала можливою внаслідок віри в існування універсальних історичних законів, на основі пізнання яких суспільство свідомо рухатиметься у напрямку реалізації спільної мети по досягненню ідеального й справедливого устрою. Причому дана ідея, яка була сформульована і теоретично розроблена в рамках європоцентристської парадигми, була характерною і для радянської, і для західноєвропейської філософської думки часів гострого соціально-політичного та світоглядного протистояння.

Серед найпоширеніших теоретико-методологічних підходів до всесвітньої історії, заснованих на ідеї європоцентризму, можна назвати ліберальний та формаційний, кожен з яких моделював майбутній пре-
\end{abstract}

Актуальні проблеми духовності 
красний стан суспільства в цілому, виходячи з власного розуміння мети історії. Досягнення такого ідеального стану власне і буде «кінцем історії». Але, як слушно зауважив Гадамер (Див.: [12, с. 493]), саме той, хто затято тримається за свої плани, першим відчує безсилля свого розуму. Спроба побудувати ідеальне суспільство, виходячи із заздалегідь визначених абстрактних моделей, далеко не завжди виправдовує оптимістичні сподівання її теоретиків. Суспільство являє собою комплексний механізм, що складається з індивідуальностей, наслідки дій яких доволі важко передбачити, причому і в матеріальній, і в духовній сферах. Усвідомлення цих обставин стає основою для сумнівів в правомірності вживання терміну «історичний закон». Грунтовний аналіз двох полярних точок зору щодо ідеї закономірного руху історії дозволить, на наш погляд, говорити про переваги і недоліки кожної з них. Слід одразу зазначити, що в даній роботі аналізуватимуться погляди марксистських філософів, які потребують переосмислення, та деяких західноєвропейських мислителів, зокрема Яна Лукасевича та Карла Поппера, котрі використовували засоби логіки при дослідження філософських проблем.

Спочатку розглянемо позицію прихильників існування історичних законів (марксистів). Вони виходять з філософської концепції детермінізму - вчення про об'єктивний закономірний взаємозв'язок та взаємообумовленість явищ матеріального і духовного світу. Ідея детермінізму виникає вже в античній філософіï, зокрема в атомістиці Левкіппа і Демокрита. Подальший розвиток та обгрунтування детермінізм отримує в природознавстві й матеріалістичній філософії Нового часу (Ф.Бекон, Г. Галілей, Р. Декарт, І. Ньютон, П.С. Лаплас, Б. Спіноза, французькі матеріалісти XVIII ст.). Показовими у даному контексті є уявлення Лапласа, в яких міститься концентрований виклад світогляду, доволі типового для більшості вчених того часу. Він вважав, що все в світі причинно обумовлене і здійснюється на основі однозначних законів. Тому ідеальним прикладом наукової теорії є небесна механіка, в котрій на основі власних законів та закону всесвітнього тяжіння вдалося пояснити усі небесні явища. Механістичний ідеал науковості використовувався Лапласом для «демаркаціі» науки від релігії та містики, що визнають «свободу волі» зовнішніх, надприродних сил і їх можливе втручання в ходу природних процесів, а також від уявлень про об'єктивну дійсність як про хаос, про реальність, якою керує пан «випадок» [6, с.3]. Проте, на нашу думку, концепція механістичного детермінізму цілком узгоджується із релігійною свідомістю. Адже т. зв. лапласівський варіант детермінізму опосередковано веде 
до фаталізму, тим самим приховано містячи в собі віру в божественне провидіння. Сам Лаплас так говорив про причинність як основу детермінації: «Розум, якому були б відомі на певний момент усі сили, що одухотворяють природу, та відносне положення усіх $\dddot{1} і$ частин ... охопив би в одній формулі рух найбільших тіл Всесвіту поряд з рухом найдрібніших атомів: не залишилося б нічого, що було б для нього недостовірним, і майбутнє, як і минуле, стало б явним» (Цит. по: [6, c. 4]).

Що стосується концепції соціального детермінізму, то вона грунтується на матеріалістичному розумінні історії. Останне виходить з положення про те, що «кінцеві причини усіх суспільних змін та політичних переворотів слід шукати не в головах людей, не в зростаючому розумінні ними вічної істини та справедливості, а в зміні способу виробництва та обміну; їх треба шукати не в філософії, а в економіці відповідної епохи» [14, с. 271]. На основі матеріалістичного розуміння історії Маркс намагався довести, що саме спосіб виробництва матеріальних благ $є$ основною детермінантою суспільного розвитку, а також визначає спрямованість, характер і зміст функціонування усіх інших підсистем (соціальної, політичної, релігійної, культурної тощо). Коли змінюється спосіб матеріального виробництва, то перетворюються й інші сторони життя суспільства. Відтак у тому, що базис породжує надбудову, проявляється необхідність у розвитку суспільства. Однак марксизм допускає поруч з необхідністю дію випадковостей, які уповільнюють або прискорюють розвиток соціуму [9, с. 199].

Таким чином, ядром марксистської концепції соціального детермінізму є ідея визнання закономірного характеру суспільного розвитку. Згідно з цією концепцією, історичні закони визначають основну лінію розвитку соціуму, але не зумовлюють розмаїття діяльності окремих людей як членів певних соціальних груп. В рамках об'єктивної необхідності-а ці рамки доволі широкі-люди можуть приймати різноманітні рішення, проявляти ініціативу відповідно до своїх інтересів, розуміння об'єктивних умов, конкретних обставин тощо [5, с. 129-130]. Саме тому кожен народ має власну історію, незважаючи на дію аналогічних законів в країнах, що мають однаковий соціально-економічний устрій.

У зв'язку з цим в межах марксизму виникає ідея про історичні закони як закони-тенденції, тобто закони, які визначають основну лінію розвитку соціуму, не охоплюючи і не зумовлюючи розмаїття випадковостей та відхилень. За таких умов, на нашу думку, спрацьовує ідея лапласівського детермінізму, оскільки домінуюча тенденція ви- 
значає результат процесу (стан макросистеми), хоча й передбачається дія імовірнісного детермінізму на рівні мікросистем, тобто мова йде про суб'єктивний фактор.

З цього приводу О.К. Улєдов застерігає проти ототожнення суспільного закону тільки з законом-тенденцією. Він зазначає, що необхідно більш чітко розрізняти зміст історичних законів і форму їх прояву, а відтак не розглядати судження про абсолютні закони та закони-тенденції як взаємовиключні. Дослідник переконаний, що визначення тих або інших законів за їх змістом як абсолютних ще не означає неможливість для них бути за своїм проявом законами-тенденціями [13, с.6364]. При капіталізмі високий рівень розвитку продуктивних сил і науки привів до зменшення впливу випадковостей на суспільне життя, викликаних стихійними силами природи. Однак, тут розширюється сфера дії випадковостей, безпосередньо пов'язаних з соціальними відносинами. Саме тому Маркс говорив про загальний закон як такий, що виражає історичну необхідність як домінуючу тенденцію (Див: [9, c. 206-207]).

Визволення людей від домінування випадковостей над ними, на думку Маркса, можливе лише за умови свідомого управління і регулювання суспільних процесів, яке стане реальністю при комунізмі. Саме тоді будуть усунені анархія і конкуренція як головні чинники фактору випадковості, а люди будуть мати ті наслідки, яких вони забажають. Отже, зростатиме роль абсолютних загальних історичних законів, хоча й діятимуть специфічні закони.

Вітчизняна філософія давно вже відмовилась від ідеї непогрішимості «єдино вірного вчення». У цьому відношенні цікавою є думка В. Будза, який підкреслює, що визнання в суспільних науках законів і закономірностей є безболісним в тому випадку, якщо науковець відстоює моністичні позиції щодо пояснення історичного процесу, і тому в даному випадку всі явища життя редукує до законів, які випливають із цього моністичного пояснення світу, з якоїсь одної основної парадигми. Якщо ж дослідник суспільного життя відстоює плюралістичні позиції, то «встановлення історичних законів і закономірностей стає проблематичним, оскільки йому необхідно враховувати всю сукупність взаємодій і сил, що мають місце і діють в суспільному житті, всю тотальність факторів і впливів» [2, с.119].

Можна також згадати в даному контексті висловлювання відомого російського історика А.Я.Гуревича, який зауважив, що з допитливого мислителя, який висунув наукову гіпотезу про виділення соціально-економічного аспекту життя суспільства як системоутворюючо- 
го, Маркс був в подальшому перетворений на намісника непогрішимої істини. Тим самим його прибічники вивели марксизм за межі науки, зробивши не предметом прискіпливого наукового аналізу, а «предметом віри і компонентом примусової ідеології тоталітарного типу» $[3$, c. 36].

Таким чином, марксистська теорія суспільного розвитку та ідея існування історичних законів у сучасній вітчизняній філософії розглядається лише як один із можливих варіантів осягнення історичної еволюції. Віра в безмежні можливості людського розуму є занадто оптимістичною. Можна стверджувати, що на сьогодні людина все ще залишається найбільшою таємницею для самої себе. Тому, на наш погляд, формулювання історичних законів є доволі ризикованою справою. Спроба розглядати історію з точки зору їі завершеності в майбутньому містить певні методологічні вади, тому що при такому підході в якості постулату приймається те, що ще необхідно довести. До того ж розроблена Марксом на матеріалі епохи початкового накопичення капіталу гіпотеза про можливість виокремлення законів суспільного розвитку багато в чому не знаходить свого підтвердження в реальному історичному процесі. Якщо в Європі нового часу соціально-економічний аспект життя соціуму виступав як провідний, то це не означає, що таким же він був і в часи первісності, і в античності, і в середньовіччі, і на Сході або в Африці, а тим паче буде в майбутньому. Ймовірно, що за аналогією зі становленням окремої особистості, історичний процес теж має т. зв. сенситивні періоди свого розвитку, тобто найбільш придатні для функціонування окремої його сфери в різні історичні епохи. Можливо, саме на це і потрібно орієнтуватися, а не дотримуватися спрощеної схеми невпинного історичного прогресу.

Критика торкнулася і гносеологічних аспектів марксистської теоpii. Зокрема Гуревич, зазначає, що марксизм в період свого становлення опинився перед вибором: його творець мав прийняти точку зору Гегеля або наслідувати ідеї Канта. Перший шлях передбачав єдність свідомості та дійсності, яку вона сприймає; світ є пізнаваним, оскільки пізнаючи світ, дух пізнає самого себе. Шлях Канта, у свою чергу, вимагав тривалої боротьби думки, яка має долати величезні перепони для того, щоб торкнутися цієї дійсності. Гуревич зазначає, що Маркс без вагань встав на позиції Гегеля, хоча і відкинувши його об'єктивний ідеалізм, але зберігши в матеріалістичній інтерпретації його панлогізм та впевненість у всемогутності пізнання [3, с.35]. А відтак, пафос єдиної науки, орієнтованої на відкриття всезагальних законів, характерний для епохи віри у безупинний прогрес, був поширений і на науки про 
суспільство.

Більш радикальні спроби переосмислення ідеї існування історичних законів були здійснені представниками аналітичного руху, які намагалися перетворити філософію на справжню науку. Зокрема, видатний логік і філософ, один із засновників польської школи математичної логіки Ян Лукасевич проголосив глобальне завдання відносно подальшого розвитку філософії: «Філософію необхідно перебудувати, починаючи з засад, вдихнути в неї науковий метод і підкріпити її новою логікою» [7, с.61]. Досягнення цієї мети передбачає і критику філософської концепції детермінізму засобами логіки. Лукасевич на основі логічних даних піддає критиці два засадничих аргументи, що свідчать на користь детермінізму: логічний принцип виключного третього та фізичний принцип причинності. Аналізуючи другий аргумент, філософ приходить до висновку про його хибність, мотивуючи це тим, що можуть існувати причинні ланцюги, які ще не почалися, а повністю лежать в майбутньому. До того ж він зауважує, що можна бути глибоко переконаним, нібито нічого не відбувається без причини, а кожна подія має своєю причиною якусь подію минулого, але, тим не менш, не бути детерміністом [7, с.67].

Аргумент, заснований на принципі виключного третього, знаходить своє підкріплення в аргументі, заснованому на принципі причинності. Однак останній не має доказової сили. Відповідно немає підстав, на думку Лукасевича, говорити і про істинність іншого аргументу, що свідчить на користь детермінізму. В результаті цих міркувань він приходить до висновку, що коли мова йде про випадкові майбутні події, які здебільшого пов'язані з діяльністю живих істот, то висловлювання про них сьогодні ще не $є$ ні істинними, ні хибними. Про це говорив і Аристотель, який сформулював аргумент на користь детермінізму, а потім сам і спростував його. Зокрема він писав: «Якщо щось буде випадково, то воно не буде по необхідності» $[1,18 \mathrm{~b}, 15-20]$. А далі додавав: «У того, що $є$ діяльнісним і непостійним, можливість бути і не бути однакова; у нього можливе і те і інше, тобто бути і не бути, а тому відбутися, і не відбутися» $[1,19 a, 5-15]$. Отже, двозначна логіка не спрацьовує, коли мова йде про майбутні одиничні випадкові події. Лукасевич пропонує ввести третє логічне значення - «невизначеність», яке б було рівнозначним з істиною і хибою. Їх онтологічними відповідниками можна вважати, на його думку, буття, небуття і можливість.

Починаючи з кінця XIX ст. в працях представників західноєвропейської філософської думки виникають й спроби критичної переоцінки принципу історизму як і класичної філософії історії в цілому. Дедалі 
зрозумілішим ставав той факт, що моністичне тлумачення історичного процесу за допомогою певних законів та закономірностей, які детермінують соціальне буття, насправді неспроможне відтворити усю його складність та багатогранність.

Одним із найбільш послідовних критиків можливості управляти історією на основі знання їі універсальних законів був видатний австро-англійський методолог і філософ науки, логік, класик світової філософії ХХ ст. Карл Раймонд Поппер, соціально-філософське вчення якого необхідно розглядати в контексті загальної концепції критичного раціоналізму. Відповідно до неї, справжня наукова теорія потребує свого потенційного спростування. Тому принцип фальсифікації виступає для нього критерієм демаркації науки від ненаукових конструкцій, а найважливішою рисою наукової діяльності $є$ визнання можливості помилкових припущень і навіть помилкових теорій, а також відмова від догматизації мислення.

На основі принципу наукового методу Поппер пропонував чітко розрізняти два підходи до вивчення соціальної історії: власне історичний (науковий) та історицистський, який веде до викривленої картини історичного руху [8, с.47]. Філософ визначає історицизм як особливий вид фаталізму по відношенню до спрямованості історії. Історицисти стверджують, що розвитком суспільства й історією управляють певні закони, на основі яких можна прогнозувати і навіть проектувати події та суспільні процеси. Тому їх потрібно пізнати і по можливості пришвидшувати втілення в життя. Натомість Поппер вважає, що фіксованим є тільки минуле. Творчість нового, в тому числі і творчість самої людини, постійно змінює всю ситуацію, обмежує наші можливості щодо передбачення майбутнього, але в той же час робить свободу волі реальним фактором в формуванні того ж таки майбутнього [15, c. 47$]^{1}$.

На підтвердження цієї тези він наводить низку аргументів для спростування історицизму як одного з методологічних підходів до вивчення історії:

(1) хода людської історії в значній мірі залежить від росту людського знання;

(2) використовуючи раціональні або наукові методи, ми не можемо передбачити, яким буде ріст наукового знання;

\footnotetext{
${ }^{1}$ Цікаво порівняти ці висновки Поппера з міркуваннями Лукасевича, що були розглянуті вище.
} 
(3) відповідно, ми не можемо передбачити хід людської історії;

(4) це означає, що ми маємо відкинути можливість теоретичної істоpiї, або такої історичної науки про суспільство, яка була б співвіднесена з теоретичною фізикою. Неможлива жодна наукова теорія історичного розвитку, яка слугувала б основою для історичного передбачення;

(5) як наслідок, основна мета історицистського методу поставлена невірно: історицизм зазнає краху [11, № 8, с.50].

Проводячи далі лінію критики історицизму, Поппер зазначає, що йому відповідає холістичний стиль мислення, для якого характерним $\epsilon$ цілісне сприйняття суспільства у його історичному розвитку. Філософ називає його ще «утопічною інженерією» на відміну від «часткової інженерії» або атомістичного підходу. Холісти планують не тільки вивчати соціум в цілому за допомогою історицистського методу, але й поставити під тотальний контроль і перебудувати його як цілісний організм. Тому холістське планування, на думку Поппера, справедливо розцінювати як утопічне, адже воно не має під собою наукових підстав. Натомість прибічник «часткової соціальної інженерії» не формулює кінцеву мету історичного процесу, не прагне радикально перебудувати суспільство, а спрямована на досягнення конкретних цілей за допомогою поступового удосконалення. Поппер зауважує, що різниця між двома видами соціальної інженерії на практиці полягає «не стільки в масштабах..., скільки в передбачливості й готовності до неминучих сюрпризів» $[11$, № 9, с. 29$]$.

Розробляючи логіку соціальних наук, видатний філософ відмічав, що ми знаємо достатньо багато, маємо глибоке теоретичне бачення i варте подиву світосприйняття. У той же час безмежним $є$ і наше незнання. Кожна вирішена проблема породжує нові. Більше того, іноді виявляється, що навіть там, де все нібито зрозуміло, з часом виникають проблеми і неточності [10, с.65]. «Частковий інженер», як і Сократ, мало знає; він розуміє, що наші знання відносні і мають властивість змінюватися з часом.

K. Поппер не заперечує існування історичних тенденцій, а лише законів. Він звертає увагу на те, що тенденція виражає основну спрямованість процесу, розвитку явища, враховуючи наявність різноманітних відхилень від кінцевого результату. Тому вона не може бути основою для достовірних наукових прогнозів. Поппер підкреслює, що головна помилка історицистів полягає у визначенні історичних тенденцій як 
абсолютних та незалежних від початкових умов, які тим самим ведуть нас у певному напрямку в майбутнє. Насправді, існує безмежна кількість імовірних умов, за яких провідна тенденція може не втілитися у життя $[11$, № 10, с. 41], а залишитися в сфері можливого.

Напевне історицистські концепції виникають у кризові періоди істоpiї, коли обмежуються базові права значної частини соціуму. Саме тоді формулюються ідеї побудови ідеального колективістського суспільства на основі історичних законів. Як правило, його автори обіцяють соціальну рівність і справедливість. Подібні моделі майбутнього уніфікують інтереси та потреби усіх людей; вони не розраховані на динамічні зміни, які лежать в основі західноєвропейської цивілізації, індивідуалістичної за своєю суттю. 3 цього приводу Поппер відмічає, що «історицисти ніби намагаються компенсувати собі втрату незмінного світу, чіпляючись за віру в те, що зміни можна передбачити, оскільки ним править незмінний закон» $[11$, №10, с. 58$]$.

Завершуючи наше дослідження, вважаємо за необхідне зазначити, що вирішення проблеми історичних законів має широкомасштабне практичне значення. Заперечення їх існування відкриває шлях до бачення численних історичних альтернатив без кінцевої напередвизначеності. Таке можливе лише за умови функціонування «відкритого», демократичного суспільства. Натомість визнання існування історичних законів таїть в собі небезпеку повернення тоталітаризму, оскільки досягнення загальної, нехай і благої, мети дуже часто стає в розріз з інтересами окремих людей. Як сказав $Ф$. Гьольдерлін, «що завжди перетворювало державу в пекло на землі, так це спроби людства зробити його земним раєм» (Цит. по: $[4$, с. 7$])$. Примара насилля в такому випадку не полишить людей у їх повсякденному соціальному бутті. Однак це не означає, що історичний процес має розглядатися як хаос розрізнених подій і явищ. У ньому діють тенденції, які не слід ототожнювати з законами в класичному їх розумінні.

\section{1 Бібліографія}

[1] Аристотель. Об истолковании // Аристотель. Сочинения в четырёх томах. - Т. 2.-М.: Мысль, 1978. - С.91-116.

[2] Будз В. Проблема визначення законів і закономірностей історичного процесу в філософсько-історичній концепції Михайла Грушевського // Людина і політика. - 2001. -№6. - С. 114-121. 
[3] Гуревич A.Я. Теория формаций и реальность истории // Вопросы философии. - 1990. - № 11. - С. 31-43.

[4] Ивин А.А. Введение в философию истории. - М.: ВЛАДОС, 1997.

[5] Келле В.Ж., Ковальзон М.Я. Теория и история: (Проблемы теории исторического процесса). - М.: Политиздат, 1981.

[6] Лебедев C.А., Кудрявцев И.К. Детерминизм и индетерминизм в развитии естествознания // Вестн. Моск. Ун-та. Сер. 7. Философия. -2005 . - № 6 . - С. 3-20.

[7] Лукасевич Я. О детерминизме // Вопросы философии. - 1995.№ 5. - C. $60-71$.

[8] Овчинников Н.Ф. Карл Поппер - наш современник, философ XX века // Вопросы философии. - 1992. - № 8. - С. 40-48.

[9] Пилипенко Н.В. Диалектика необходимости и случайности. - М.: Мысль, 1981.

[10] Попnер K. Логика социальных наук // Вопросы философии. 1992. - № 10. - C. $65-75$.

[11] Поппер К. Нищета историцизма / / Вопросы философии. - 1992. № 8. - С.49-79; № 9. - C.22-48; № 10. - С. 29-58.

[12] Сергейчик E.M. Философия истории.-СПб.: Лань, Санкт-Петкий ун-т МВД России, 2002.

[13] Уледов А.К. Социологические законы.-М.: Мысль, 1975.

[14] Энгельс Ф. Анти-Дюринг. Переворот в науке, произведённый господином Евгением Дюрингом.-М.: Политиздат, 1983.

[15] Юлина Н.С. Философия Карла Поппера: мир предрасположенностей и активность самости // Вопросы философии. - 1995. № $10 .-$ С. $45-56$. 